\title{
The Origin and Scale of Gender Inequality: Evidence from a Natural Experiment
}

\author{
Authors: Jason Radford ${ }^{1,2} *$
}

\author{
Affiliations: \\ ${ }^{1}$ University of Chicago, Chicago, IL 60637 USA. \\ ${ }^{2}$ Northeastern University, Boston, MA 02115 USA. \\ *Correspondence to: j.radford@neu.edu.
}

\begin{abstract}
In the United States, women make roughly $75 \%$ of what men make. This inequality is reduced to roughly $92 \%$ once factors like occupation and job performance are controlled. The central debate over which number is correct has been whether these occupational and behavioral inequalities are related to gender or incidental to it. This study uses a natural experiment from a crowdfunding website for public school teachers to answer this question. The study shows there is no occupational and behavioral inequality in the likelihood of funding when teachers are anonymous. Yet, there is substantial inequality after they are identified as "Mr. Smith" or "Ms. Jones." These results indicate gender gaps by occupation and behavior only occur as a result of exposure to gender and that estimates of gender inequality are likely under-inflated by thirty percent.
\end{abstract}

One Sentence Summary: Discrimination by occupation and behavior are caused by gender bias and directly contribute to the total amount of gender inequality.

\section{Main Text}

The gender wage gap in the United States has been roughly 75 cents on the dollar for the past three decades $(1,2)$. This gap persists despite policies and public opinion affirming the right of women to work, support for equal pay, and increases in the number of educated and experienced women in the workforce $(1-4)$.

However, when occupation, industry, education, working conditions, and work experience are controlled, the gender wage gap decreases substantially $(1,2,5,6)$ or, in some cases, disappears completely (7). Studies consistently show structural characteristics like occupation explain between twenty and forty percent of the gender gap while behavioral characteristics like hours worked, work experience, and having children explain another twenty to forty percent. The residual gap, equivalent to between five and fifteen cents on the dollar, is attributed to sex discrimination $(2,5,6)$.

Many argue however these occupational and behavioral variables should not be controlled away. They claim this inequality is caused by gender (8-9). Net of average education, skill, and demand for workers, occupations and industries with more women have lower wages (10). And, behaviors rewarded by employers like working long hours, being devoted to a career, foregoing family events and responsibilities, and being willing to relocate are those seen as appropriate for men and not women (11-13). This body of research indicates there is a bias in favor of male-typical jobs and a preference for people who behave in masculine ways. 
The debate over whether gender bias causes inequalities between occupations and work behaviors has largely been based on observational studies of wages, case studies of organizations, and laboratory experiments with students. Field experiments in gender discrimination only look to detect discrimination by sex not occupation or behavior $(14,15)$. No study has looked at whether inequality by occupational or behavioral differences are caused by gender bias in a field setting. The study here provides the first such causal evidence using data from a natural field experiment conducted by a crowdfunding website for public school teachers in the United States. The results show that, when teachers requesting funds were anonymous, occupation and behavior had no bearing on funding. Only after teachers identities are revealed do these inequalities emerge. This provides direct, causal evidence these inequalities are a direct result of gender bias. The data suggests that if we include occupational and behavioral discrimination along with sex discrimination in our estimates of total gender inequality the gender gap increases to as high as .57 to 1 .

Methods

The natural experiment occurred on DonorsChoose.org, a crowdfunding website where public school teachers in the United States request funding for resources like computers or books. The way it works is that a teacher picks the resource they want from an online catalogue and creates a project to fund that resource. The teacher provides data about themselves and their students and writes an essay describing why they need the resource. Donors, most of whom the teacher has probably never met (see supplement), then commit money to that project. If the teacher makes enough money to cover the cost of the resource, DonorsChoose collects money from donors and sends the teacher the resource.

The experiment began in January 2008 (16). Before this time, teachers who posted projects were anonymous to donors. Starting in January 2008, teachers' identity was made public on their project proposal pages in the form "Mr. Chen" or "Ms. Rodriguez," which systematically revealed every teachers' sex category. The question I investigate is whether teachers' likelihood of funding was influenced by teacher's sex (being male or female) and their occupational or behavioral characteristics (being in a female-typical subfield of education or presenting themselves in a feminine or masculine way) and whether these influenced changed after teachers deanonymization in January 2008. If none of the gender variables affect teachers' likelihood of success until after deanonymization, then this provides causal evidence that this inequality is the direct result of gender bias among donors.

To identify whether the likelihood of funding success was influenced by sex, occupation, or behavior, I create a measure for each (see Supplementary Material). This three-dimensional approach to gender inequality is consistent with Gender System theory put forward by $(17,18)$. First, to identify whether there were any differences in funding by teachers' sex, I created a dummy variable for whether requesters were male.

Following $(9,19)$, I use the degree of sex segregation within subfields to identify the role of occupational gender in funding. Specifically, I measure the concentration of males in each subfield in education by estimating the probability a project was created by a male teacher conditional on the project's grade level, subject area, school type (traditional public school or non-traditional public school), and type of district (rural, suburban, or urban). I use the probability of a male teacher to maintain directional consistency - increasing values represent higher concentrations of male teachers.

Finally, I identify the effect of gendered behavior on funding by measuring whether teachers used masculine or feminine language in their project essays. Specifically, I text 
classification to predict the probability that an essay was written by a male or female educator. While the three measures; sex, male concentration, and masculine language; were strongly correlated with one another, the standardized Cronbach's alpha for the three was only .62 indicating that they measure related but different phenomena.

To model gender inequality, I estimate the probability an individual project was successfully funded conditional on all three gender variables and their interactions with one another. Prior research shows that, in addition to directly influencing funding, the three measures interact with one another in distinct ways $(20,21)$. I control for project-level and school-level variables and include monthly fixed effects to control for seasonality (see Supplementary Materials).

I use a regression discontinuity approach for causal identification: estimating the presence of gender inequality before and after the publication of teachers' identities. Following prior research, we should expect gendered behavior and occupation to account for 20-40 percent of the gap between men and women. However, if these inequalities do not occur until 2008, then we can say that these forms of inequality are caused by gender biases held by donors and elicited by deanonymization. If occupation and behavior affect the likelihood of funding before 2008 or their effects do not change in 2008, then we can conclude that donor preferences for certain subfields or behaviors are independent of gender. Table 1 indicates the former is the case. $\underline{\text { Results }}$

In the two years preceding the publication of teachers' identities, Models 1A and 1B show there is little relationship between the probability of funding and the gender-related variables of interest. In contrast, the models for projects posted in 2008 and 2009 (Models 1C and 1D) show substantial relationship between gender and the probability of receiving funding. Each effect becomes significant at the $\mathrm{p}>.99$ or higher level and the coefficients increase in size by a factor of between two and ten. The only exception is the direct effect of language which decreased in size and became statistically indistinguishable from zero in 2008, but reemerges in 2009.

The models in Table 1 show a male-oriented preference across the three variables and their interactions. In 2008, teachers classifying themselves as male were 27 percent more likely to receive funding than female teachers (22). Projects in a subfield that was one standard deviation more male-concentrated were 64 percent more likely to receive funding than those in a subfield with an average male-concentration. Based on the effect as measured in 2009, a one standard deviation increase in an essay's masculinity corresponds to a fifteen percent increase in the likelihood of funding.

Among the interaction effects, people using masculine language in more maleconcentrated subfields were an additional 14 percent more likely to receive funding in 2008. There was no effect for males using masculine language or for the interaction of all three variables. The one negative effect was for the interaction of sex and segregation. Teachers identifying as male in more male-concentrated subfields were less likely to receive funding: a 16 percent decrease in the likelihood of success per standard deviation increase in maleconcentration.

These results give us some sense of the scale of gender inequality. The models are consistent with what most research on income inequality has found. When occupation and behavior are controlled for in Model 1C, this gap in the probability of funding between males and females is $.92: 1$ or eight percent. If occupation and behavior are excluded from the model (not shown), the gap grows to $.72: 1$. 
However, since inequality by occupation and behavior only emerge after deanonymization, this study indicates that rather than controlling these away, we should add the direct effects of occupation and behavior to our estimate of gender inequality. When we do this, the gap in funding on DonorsChoose exceeds 72 percent. Holding the control variables constant, in 2008 , a project created by a male in a subfield with one standard deviation higher male concentration and one standard deviation more masculine language had a 68 percent chance of succeeding. A project created by a female in a one standard deviation more female-concentrated subfield and one standard deviation more feminine language had just a 39 percent chance of funding. This equates to a $.57: 1$ ratio. In 2009 , these numbers were 86 and 58 percent, a $.67: 1$ ratio.

Discussion

This is the first study of gender inequality in a real-world market where anonymity is exogenously varied and where we can estimate the contribution of sex, occupational, and behavioral biases to the overall gap. The study provides firm evidence that there are no differences in valuation between male- and female-dominated fields and male- and female-typed behavior until gender is triggered. Research on priming helps explain why donors would suddenly begin discriminating based on occupation and language. Blair (23) shows people's interpretation of a situation and evaluation of others changes when gender is made salient.

Before sex was published on DonorsChoose, donors valued female-typical subfields like teaching language arts in a traditional rural elementary school as much as teaching history in an urban charter high school. Donors also found masculine and feminine language equally compelling. However, once sex was published, donors began to think differently about the language teachers used and the kinds of jobs they held in ways that disadvantaged people in female-typical subfields and people using feminine language.

The results suggest that estimates of gender inequality must take all three variables and their interactions into account to accurately estimate inequalities due to gender bias. Most studies of wage and income inequality only measure occupational and sex inequality. Based on this study, this omission may lead us to underestimate gender inequality by roughly one third. This suggests that, if properly estimated, the gender gap in income in the United States may actually be closer to 63 cents on the dollar.

For policy-makers and practitioners looking to end gender inequality, this study provides further support for implementing gender-blind hiring, wage-setting, and promotion systems. Gender-blind processes should not only eliminate inequality between men and women but also between different types of jobs and behaviors seen as typical of men and women.

However, the implications of this study extend further, suggesting the need for a reevaluation of wages across industries and occupations. If the gap in pay between police officers and teachers, people with MBAs and those with MSWs, or biologists and physicists is caused by the fact that people see men in one and women in the other, then the gender gap will only be closed through cross-sector initiatives disentangling gender discrimination from pay across sectors.

\section{References and Notes:}

1. F. D. Blau, L. M. Kahn, The US gender pay gap in the 1990s: Slowing convergence. Industrial \& Labor Relations Review. 60, 45-66 (2006).

2. F. D. Blau, L. M. Kahn, "The gender wage gap: Extent, trends, and explanations" (National Bureau of Economic Research, 2016), (available at http://www.nber.org/papers/w21913). 
3. D. Cotter, J. M. Hermsen, R. Vanneman, The End of the Gender Revolution? Gender Role Attitudes from 1977 to 2008. American Journal of Sociology. 117, 259-89 (2011).

4. K. Donnelly et al., Attitudes toward women's work and family roles in the United States, 1976-2013. Psychology of Women Quarterly. 40, 41-54 (2016).

5. C. Goldin, A grand gender convergence: Its last chapter. American Economic Review. 104, 1091-1119 (2014).

6. D. Card, A. R. Cardoso, P. Kline, Bargaining, sorting, and the gender wage gap: Quantifying the impact of firms on the relative pay of women (National Bureau of Economic Research, 2015), (available at http://www.nber.org/papers/w21403).

7. J. O'Neill, The gender gap in wages, circa 2000. The American Economic Review. 93, 309314 (2003).

8. H. M. Lips, The gender pay gap: Challenging the rationalizations. Perceived equity, discrimination, and the limits of human capital models. Sex Roles. 68, 169-185 (2013).

9. B. F. Reskin, D. D. Bielby, A sociological perspective on gender and career outcomes. Journal of Economic Perspectives, 71-86 (2005).

10. P. England, P. Allison, Y. Wu, Does bad pay cause occupations to feminize, Does feminization reduce pay, and How can we tell with longitudinal data? Social Science Research. 36, 1237-1256 (2007).

11. J. Acker, Hierarchies, jobs, bodies: A theory of gendered organizations. Gender \& Society. 4, 139-158 (1990).

12. M. Blair-Loy, Competing devotions: Career and family among women executives (Harvard University Press, Cambridge, 2009).

13. J. Williams, Unbending Gender: Why Family and Work Conflict and What to Do About It (Oxford University Press, Oxford, 2000).

14. C. Goldin, C. Rouse, Orchestrating impartiality: The impact of "blind" auditions on female musicians. American Economic Review,. 90, 715-41 (2000).

15. M. Bertrand, S. Mullainathan, Are Emily and Greg more employable than Lakisha and Jamal? A field experiment on labor market discrimination. American Economic Review. 94, 991-1013 (2004).

16. The timing of the natural experiment was identified using archived versions of the DonorsChoose website captured by the Internet Archive.

17. C. L. Ridgeway, S. J. Correll, Unpacking the gender system: A theoretical perspective on gender beliefs and social relations. Gender \& Society. 18, 510-531 (2004).

18. B. J. Risman, Gender as a social structure: Theory wrestling with activism. Gender \& Society. 18, 429-450 (2004).

19. B. F. Reskin, D. B. McBrier, J. A. Kmec, The determinants and consequences of workplace sex and race composition. Annual Review of Sociology. 25, 335-361 (1999).

20. C. West, D. H. Zimmerman, Accounting for doing gender. Gender \& Society. 23, 112-122 (2009).

21. W. Wood, A. H. Eagly, A cross-cultural analysis of the behavior of women and men: Implications for the origins of sex differences. Psychological Bulletin. 128, 699-727 (2002).

22. Because the model is a logistic regression, the coefficients are log odds ratios. And, since the male variable is $\mathrm{z}$-score standardized, it is no longer a $\{0,1\}$ binary. When standardized, males have a value of 2.65 and females have a value of -0.377 . Thus, the odds ratio for male funding success is calculated as $\exp \left(2.65^{*} .08\right)$, which equals an odds ratio of 1.24. 
23. I. V. Blair, The malleability of automatic stereotypes and prejudice. Personality and Social Psychology Review. 6, 242-261 (2002).

24. J. M. Robins, M. A. Hernán, B. Brumback, Marginal structural models and causal inference in epidemiology. Epidemiology. 11, 550-560 (2000).

25. S. R. Cole, M. A. Hernán, Constructing inverse probability weights for marginal structural models. American Journal of Epidemiology. 168, 656-664 (2008).

26. J. Grimmer, B. M. Stewart, Text as data: The promise and pitfalls of automatic content analysis methods for political texts. Political Analysis, 267-297 (2013).

27. J. A. Evans, P. Aceves, Machine translation: Mining text for social theory. Annual Review of Sociology. 42, 21-50 (2016).

28. E. Frank, R. R. Bouckaert, Naive Bayes for text classification with unbalanced classes Proceedings of the 10th European Conference on Principle and Practice of Knowledge Discovery in Databases (Springer-Verlag, Berlin, Heidelberg, 2006; http://dx.doi.org/10.1007/11871637_49), PKDD’06, pp. 503-510.

29. F. Pedregosa et al., Scikit-learn: Machine learning in Python. Journal of Machine Learning Research. 12, 2825-2830 (2011).

30. C. D. Manning, P. Raghavan, H. Schütze, Introduction to Information Retrieval (Cambridge University Press, Oxford, 2008).

31. H. A. Schwartz et al., Personality, gender, and age in the language of social media: The open-vocabulary approach. PLoS ONE. 8, e73791 (2013).

32. S. Argamon, M. Koppel, J. Fine, A. R. Shimoni, Gender, Genre, and Writing Style in Formal Written Texts. Text. 23, 321-346 (2003).

33. M. R. Mehl, S. D. Gosling, J. W. Pennebaker, Personality in its natural habitat: Manifestations and implicit folk theories of personality in daily life. Journal of Personality and Social Psychology. 90, 862-877 (2006).

34. M. L. Newman, C. J. Groom, L. D. Handelman, J. W. Pennebaker, Gender differences in language use: An analysis of 14,000 text samples. Discourse Processes. 45, 211-236 (2008).

35. H. Zhang, The optimality of naive Bayes. AA. 1, 3 (2004).

36. S. Argamon, M. Koppel, J. W. Pennebaker, J. Schler, Mining the blogosphere: Age, gender and the varieties of self-expression. First Monday. 12 (2007).

37. S. Thebaud, A. Sharkey, Unequal hard times: The influence of the Great Recession on gender bias in entrepreneurial financing. Sociological Science. 3, 1-31 (2016).

Acknowledgments: Special thank you to Jim Murphy and Forest Gregg at the University of Chicago and my colleagues at the Lazer Lab at Northeastern University who have given me extensive feedback on the analysis presented. Thanks also to Professors Elisabeth Clemens, Kristen Schilt, and James Evans at the University of Chicago and David Lazer at Northeastern University who provided guidance at various stages. Finally, this research has benefited from feedback from presentations given at the Social Theory and Evidence Workshop and the Computational Social Science workshop at the University of Chicago, the Economic Sociology Working Group at MIT, Collective Intelligence, the Association for Computational Linguistics, and the American Sociological Association. Replication code and data used in this paper are stored at Harvard's Dataverse. 


\begin{tabular}{|c|c|c|c|c|}
\hline Variables & $\begin{array}{c}2006 \\
\text { Model } \\
\text { 1A }\end{array}$ & $\begin{array}{c}2007 \\
\text { Model } \\
\text { 1B }\end{array}$ & $\begin{array}{c}2008 \\
\text { Model } \\
1 \mathrm{C}\end{array}$ & $\begin{array}{c}2009 \\
\text { Model } \\
\text { 1D }\end{array}$ \\
\hline (Intercept) & $\begin{array}{l}7.604 * * * \\
(0.393)\end{array}$ & $\begin{array}{l}8.516 * * * \\
(0.383)\end{array}$ & $\begin{array}{l}9.330 * * * \\
(0.312)\end{array}$ & $\begin{array}{l}5.336 \text { *** } \\
(0.239)\end{array}$ \\
\hline Male $^{\mathrm{s}}$ & $\begin{array}{l}0.050 \\
(0.035)\end{array}$ & $\begin{array}{l}0.049 \\
(0.031)\end{array}$ & $\begin{array}{l}0.080 * * * \\
(0.024)\end{array}$ & $\begin{array}{l}0.072 * * * \\
(0.021)\end{array}$ \\
\hline Male Concentratoin $\mathrm{S}, \mathrm{L}$ & $\begin{array}{l}0.122 \\
(0.065)\end{array}$ & $\begin{array}{l}0.139 * \\
(0.058)\end{array}$ & $\begin{array}{l}0.496 * * * \\
(0.046)\end{array}$ & $\begin{array}{l}0.579 * * * \\
(0.040)\end{array}$ \\
\hline Masculine Language ${ }^{\mathrm{S}}$ & $\begin{array}{l}0.023 \\
(0.069)\end{array}$ & $\begin{array}{l}0.151 * \\
(0.062)\end{array}$ & $\begin{array}{l}0.037 \\
(0.049)\end{array}$ & $\begin{array}{l}0.139 * * * \\
(0.039)\end{array}$ \\
\hline Male $^{\mathrm{S}} \times$ Male Concentration $\mathrm{s}$ & $\begin{array}{l}-0.031 \\
(0.031)\end{array}$ & $\begin{array}{l}-0.007 \\
(0.027)\end{array}$ & $\begin{array}{l}-0.066^{* *} \\
(0.021)\end{array}$ & $\begin{array}{l}-0.047 * \\
(0.019)\end{array}$ \\
\hline Male $^{\mathrm{S}} \mathrm{x}$ Masc Language ${ }^{\mathrm{S}}$ & $\begin{array}{l}-0.007 \\
(0.033)\end{array}$ & $\begin{array}{l}0.003 \\
(0.030)\end{array}$ & $\begin{array}{l}-0.009 \\
(0.024)\end{array}$ & $\begin{array}{l}0.007 \\
(0.020)\end{array}$ \\
\hline Male Concentration ${ }^{\mathrm{S}, \mathrm{L}} \mathrm{x}$ Masc Language ${ }^{\mathrm{S}}$ & $\begin{array}{l}0.007 \\
(0.056)\end{array}$ & $\begin{array}{l}-0.009 \\
(0.050)\end{array}$ & $\begin{array}{l}0.138 * * * \\
(0.040)\end{array}$ & $\begin{array}{l}0.123 * * * \\
(0.034)\end{array}$ \\
\hline Male $^{\mathrm{S}} \mathrm{x}$ Male Concentration ${ }^{\mathrm{S}, \mathrm{L}} \times$ Masc Langauge $\mathrm{S}^{\mathrm{S}}$ & $\begin{array}{l}0.028 \\
(0.028)\end{array}$ & $\begin{array}{l}0.018 \\
(0.025)\end{array}$ & $\begin{array}{l}0.010 \\
(0.02)\end{array}$ & $\begin{array}{l}-0.024 \\
(0.018)\end{array}$ \\
\hline Ask for Trips & $\begin{array}{l}-0.006 \\
(0.157)\end{array}$ & $\begin{array}{l}-0.130 \\
(0.217)\end{array}$ & $\begin{array}{l}1.486 * * * \\
(0.341)\end{array}$ & $\begin{array}{l}1.645^{* * * *} \\
(0.357)\end{array}$ \\
\hline Ask for Visitors & $\begin{array}{l}-0.270 \\
(0.370)\end{array}$ & $\begin{array}{l}-0.127 \\
(0.518)\end{array}$ & $\begin{array}{l}0.110 \\
(0.674)\end{array}$ & $\begin{array}{l}0.285 \\
(0.624)\end{array}$ \\
\hline Ask for Books & $\begin{array}{l}0.034 \\
(0.098)\end{array}$ & $\begin{array}{l}0.107 \\
(0.089)\end{array}$ & $\begin{array}{l}0.270 * * * \\
(0.067)\end{array}$ & $\begin{array}{l}0.412 * * * \\
(0.059)\end{array}$ \\
\hline Ask for Technology & $\begin{array}{l}-0.552 * * * \\
(0.083)\end{array}$ & $\begin{array}{l}-0.633 * * * \\
(0.078)\end{array}$ & $\begin{array}{l}-0.423 * * * \\
(0.059)\end{array}$ & $\begin{array}{l}-0.397 * * * \\
(0.049)\end{array}$ \\
\hline Ask for Other & $\begin{array}{l}0.153 \\
(0.138)\end{array}$ & $\begin{array}{l}0.004 \\
(0.130)\end{array}$ & $\begin{array}{l}-0.334 * * * \\
(0.096)\end{array}$ & $\begin{array}{l}-0.189^{*} \\
(0.085)\end{array}$ \\
\hline \# of Students Reached ${ }^{\mathrm{L}}$ & $\begin{array}{l}-0.063^{*} \\
(0.030)\end{array}$ & $\begin{array}{l}-0.095^{* *} \\
(0.029)\end{array}$ & $\begin{array}{l}-0.105 * * * \\
(0.023)\end{array}$ & $\begin{array}{l}-0.171 * * * \\
(0.020)\end{array}$ \\
\hline Price of Project ${ }^{\mathrm{L}}$ & $\begin{array}{l}-1.140 * * * \\
(0.048)\end{array}$ & $\begin{array}{l}-1.466 * * * \\
(0.053)\end{array}$ & $\begin{array}{l}-1.685^{* * * *} \\
(0.047)\end{array}$ & $\begin{array}{l}-0.818 * * * \\
(0.033)\end{array}$ \\
\hline School Poverty & $\begin{array}{l}0.520 * * * \\
(0.092)\end{array}$ & $\begin{array}{l}0.641 * * * \\
(0.070)\end{array}$ & $\begin{array}{l}0.770 * * * \\
(0.055)\end{array}$ & $\begin{array}{l}0.681 * * * \\
(0.044)\end{array}$ \\
\hline AIC & 5733 & 7102 & 11184 & 16635 \\
\hline $\mathrm{N}$ & 5040 & 7352 & 10955 & 16035 \\
\hline df & 27 & 27 & 27 & 27 \\
\hline
\end{tabular}

Table 1. Generalized linear models predicting the probability of successful funding 2006 (Model 1A) through 2009 (Model 1D). Note, monthly fixed effects were included but not reported for space. ${ }^{\mathrm{S}}$ Variable is $\mathrm{Z}$-score standardized; ${ }^{\mathrm{L}} \mathrm{Log}$ of the variable is used. $* * * \mathrm{p}<$ $.001, * * \mathrm{p}<.01, * \mathrm{p}<.05$ (two-tailed z-tests). 


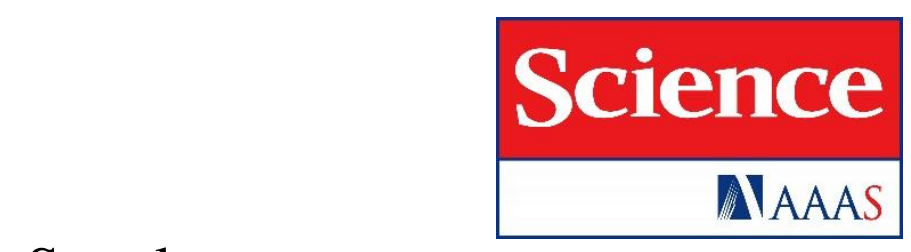

Supplementary

Materials for

The Origin and Scale of Gender Inequality: Evidence from a Natural Experiment

Jason Radford

correspondence to: j.radford@neu.edu

\section{This PDF file includes:}

Materials and Methods

Supplementary Text

Figs. S1 to S4

Tables S1 to S6 


\section{Materials and Methods}

Materials: DonorsChoose Overview and Participants

DonorsChoose is a crowdfunding website for teachers founded in 2000. Between 2002 and 2010, the period covered by the data made available for this project, more than 90,000 teachers from over 40,000 schools posted over 290,000 projects. In that time, donors gave a total of $\$ 129$ million through the market.

The experience of seeking funding through DonorsChoose has remained relatively stable since its founding. Let's say a kindergarten teacher wants a set of books for his classroom so students can learn to read. The teacher would create an account on DonorsChoose and fill out basic information about himself and his classroom. He would then create a project proposal requesting the books and write an essay about why donors should fund his project. Once complete, the project information is vetted by DonorsChoose staff and posted on the website.

Once the project is posted, anyone can donate money to it through the DonorsChoose website. If the project is fully funded, it is closed and the DonorsChoose staff purchases the books and sends them to the teacher. In some cases, the teacher might send thank-you packages to donors. These packages typically include an impact letter from the teacher, thank you letters written by students, and photos of students reading the books. If the project does not meet its goal by the expiration date, the teacher receives nothing (though this policy has changed since 2015).

Methods: Measuring Sex

Sex is a dummy variable for whether a teacher selected a male ("Mr.") or female ("Mrs." And "Ms") honorific. Even though teachers' names were not published until 2008, they still provided their titles "Mr.," "Mrs.," and "Ms." For this analysis, the "male' variable is coded as ' 1 ' for teachers who reported their title as "Mr." and ' 0 ' for those who reported "Ms." or "Mrs." Only 1,848 teachers (0.6 percent) did not provide one of these three titles and were excluded from the analysis. Eighty percent of these reported "Dr." as their title and the remaining twenty percent entered no title.

Fig. S1A shows the representation of male teachers on DonorsChoose throughout the period of interest. Male teachers account for between eight and sixteen percent of the projects posted on DonorsChoose. The frequency of male and female teachers becomes distinctly seasonal from 2007 onward. The dashed line for the raw number of male teachers indicates that this is likely due to both an increase in females and decrease in males during the summer months. Therefore, fixed effects for the month a project was posted are important controls for seasonal patterns in funding.

Methods: Measuring Occupational Segregation

The classic measure for whether an occupation may be subject to gender bias is the extent to which it is gender segregated $(9,19)$. The more segregated a job, the more gendered it is taken to be. Here I measure segregation as the proportion of male teachers in each subfield. To do this I create a generalized linear model using the occupational characteristics grade level, subject area, whether the school was traditional or an alternative public school (i.e. a charter, magnet, or year-round school), and whether the school was in an urban, suburban, or rural area (Table S1). The most female typical subfield was teaching language arts in a traditional, rural, elementary school. The most male-typical subfield was teaching social science or sports in alternative, urban, high 
schools. These are consistent with data from the Schools and Staffing Survey produced by the U.S. Department of Education's National Center for Education Statistics.

Fig. S1B is a plot of the relationship between the predicted and observed probabilities with a line of perfect fit. The figure shows how closely the model estimates gender segregation in general, but also shows heteroscedasticity in that the estimates fit less well as the estimated proportion of male teachers increases. Because of the degree of gender segregation within education, the occupational score is heavily skewed. To produce unbiased estimates for the effect of segregation on funding, I tested two corrections: taking a logarithm of the estimated probability and inverting the probability to create inverse probability weights $(24,25)$. Both methods eliminated heteroskedasticity and yielded the same results in the analysis. For clarity and consistency, I report the results based on taking the logarithm because it maintains the same sign as the other variables of interest - larger values are masculine and smaller values feminine. Methods: Measuring Gendered Behavior

I measure the gender of teachers' behavior by the extent to which they use maletypical or female-typical language in their essays. Specifically, I use supervised learning to estimate the likelihood that an essay was written by a male teacher given the words they use $(26,27)$.

The data present two unique challenges. First, the rarity of male teachers produces an imbalanced sample causing biased estimates in text classification (28). Second, because education is so sex segregated, the words that best predict an author's sex are occupational (e.g. "kindergarten," "twelfth grade").

To solve both problems, I balance my sample by sex and occupation using exact matching. I generate a sample of 228,455 essays that have the same exact occupational variables as at least one other essay (from Table 1). For each set of matched essays, I randomly selected an equal number of male- and female-authored essays. The result is a sample of 56,980 project essays balanced on occupational characteristics with half written by male teachers and half by female teachers.

I use standard supervised learning techniques contained in the scikit-learn package for python (29) to calculate the likelihood the author of an essay is male (30). For feature selection, I chose a bag-of-words approach because prior work has shown that few words consistently predict author sex across domains (31-34). I transform essays into weighted counts of words using term-frequency inverse document frequency (TFIDF). This produces an E $\mathrm{x} \mathrm{W}$ matrix where each row represents an essay, each column is a word, and the value in each cell is the TFIDF-weighted estimate of the frequency word $j$ occurred in essay $i$.

For estimation, I used a Naïve Bayes (NB) classifier because its behavior is well understood (35) and it produces estimates for which features are most discriminative (Table 2 below), allowing for a validation that the model is detecting gender differences. I also performed the analysis with SVM and none of the results of the study differed. I used 10-fold cross-validation to generate the estimate. This means I used $90 \%$ of the sample to train the classifier, the estimate the likelihood of an author's sex for the final $10 \%$, and normalize them as log likelihoods. This is repeated ten times such that each $10 \%$ subsample is held out once. The reason for using different samples to train a model and calculate estimates is to prevent over-fitting. By splitting the data repeatedly, the many random differences wash out. 
Fig. S1C shows that the accuracy of the Naïve Bayes (NB) and Support Vector Machine (SVM) based models increases as the threshold for including an estimate increases. Specifically, the closer to 50:50 the threshold for including an estimate is (zero in the figure), the less accurate models. The more extreme the likelihood estimates, the more accurate the models become. This supports the argument that larger estimates correspond to more extreme gender differentiation.

Finally, Table S2 lists the top 24 most informative words for males and females from the NB classifier. Without a linguistic theory of gender, interpreting why certain words distinguish male and female texts should be treated with caution. As in other studies, the words the classifier reported as most informative are domain-specific (36) indicating that the differences the classifier detects are substantive, rather than random noise or irrelevant verbiage. Female teachers tend to refer to students as "children," "learners," or "readers"; use verbs like "help," "want," "need," "feel," and "love" and ask for "material," "supplies," and "books." Male teachers tend to refer to "kids" or "people;" use few distinct verbs, ask for "computers," "equipment," "technology," and "video" and refer to "college," "course," and "instruction."

Methods: Model Selection

In this study, I estimate gender inequality as the extent to which the three variables of interest; sex, occupational segregation, and gendered language; predict a binary variable for whether teachers were successfully funded. The controls in the model were chosen from among the remaining characteristics educators provide to donors as well as monthly fixed effects (see Table S3). Control variables were: 1) the (logged) price of the project request, 2) a three-tiered variable for the poverty level of the school, calculated by DonorsChoose and based on the percentage of students with governmentsubsidized lunch; 3) A five category typology for the resource an educator requests; and 4) the (logged) number of students impacted or "reached." Control variables for macroeconomic factors and educators' social networks are addressed in the alternative models discussed in the next section.

I use generalized linear regression with a binomial link function to estimate the model. However, I considered using what could have been a more robust multi-level model. I decided against this because the requisite data structure of multiple projects nested within teachers within schools was the exception rather than the rule. Most teachers only posted one project and among those who posted multiple projects, many changed grades, subject areas, and schools between projects. A multi-level model would both significantly limit the statistical power of the model and shrink the scope of the analysis to some of the most atypical cases on the website.

There are several variables I do not use in the published model. First, educators reported whether the project was to fund resources for essential or enrichment activities and whether the resources would be used by future students. Neither of these variables significantly affected a project's chances of success and did not affect the estimated coefficients of other variables. In fact, they are no longer published on the DonorsChoose. Second, I also exclude variables for whether projects were eligible for matching grants and whether they received donations from a giving page, both of which strongly predict funding. These variables are causal mediators for the relationship between gender and funding and therefore cannot be included as controls. Thus, the published model should be interpreted as the probability of funding conditional on the 
project being posted by a male or female using masculine or feminine language in a male- or female-typical subfield.

\section{Supplementary Text}

This study hinges on the timing of changes to the website in January 2008.

Because gender variables become large and significant during this time, I conclude that they are caused by the publication of gender and are therefore forms of gender bias. At the same time, two other contemporaneous changes occurred that could account for the emergence of gender inequality. The first is the financial crisis. I show that the crisis had relatively little effect on the market. The second is the nationalization of the website in the Fall of 2007. I show that teachers using the website before it nationalized had developed networks of prior donors that insulated them from some of the discriminatory effects of the publication of their identities. However, the donor networks formed after 2008 were biased in the same way that teacher success was biased, causing donor networks to perpetuate gender inequality. Alternative 1: The Financial Crisis

Macro-economic trends can be a significant factor in gender inequality. In late 2008, the financial sector of the U.S. economy collapsed. The Dow Jones Industrial Average reached a peak of almost 14,000 in October 2007 and, by October 2008, closed below 10,000 for the first time in six years. The index eventually reached its nadir of 6,500 in March 2009.

These changes correspond roughly to changes in gender discrimination on DonorsChoose and offer an alternative mechanism for explaining the emergence of gender discrimination. The financial crisis may have caused a decline in donations resulting in economic scarcity which could then have caused inequality to emerge. For example, (37) found that, during the recession, women-led firms were more likely to be denied small business loans as compared to male-led firms.

Scarcity appears not to have occurred however (Fig. S2). During the period of interest, the number of donations per project increased from two to five, the average amount of money requested by teachers declined from $\$ 900$ to $\$ 600$, and the likelihood of receiving at least one donation increased from 65 to 85 percent. As Fig S2 shows, the probability of success remains within a relatively stable, seasonal cycle throughout the period of interest except for reaching a brief minimum during the summer of 2008. This contrasts with the inverted-v shape of large-scale macro-economic trends represented by the Down Jones Industrial Average also shown in Fig S2. The increase in the number of projects during the recession was met with more donations spread across more projects. Finally, no change was observed when Models 1B-D from Table 1 were re-run with a control for the value of the Dow Jones Industrial Average at the beginning of the month when a project was posted (not shown).

These results provide no evidence regarding whether scarcity affected discrimination. In this case, there was very little evidence that competition tightened. One possible reason is that demand and supply adjusted simultaneously. Another possibility is that the process of nationalization brought in more new donors off-setting any macroeconomic declines. In any case, there is no evidence that the recession caused inequality to emerge.

Alternate 2: Nationalization and Teachers' Social Networks 
Another potential confounding effect is the expansion of eligibility to the whole United States beginning in the fall of 2007. Prior to that, educators in only 11 states including New York, South Carolina, and California were eligible to seek funding through DonorsChoose. The nationalization of the website was met with a quick influx of new educators and donors from vastly different parts of the United States. These demographic changes could have affected patterns of inequality by bringing new donors with different preferences into the market or by changing the kinds of projects available for funding.

In this section, I compare the patterns of inequality for teachers on the website before nationalization to those coming after. I find that projects from teachers whose first project was posted after nationalization experienced discrimination while projects posted by teachers who had posted at least one project before nationalization did not. Teachers who posted projects before nationalization received donations from donors who had given to them before. They were thus insulated from the effects of DonorsChoose publishing teachers' sex. Once I add controls for whether teachers received donations from prior donors, I find discrimination did occur after 2007 for projects posted by teachers who were on the website prior to nationalization. Finally, I find that the publication of teachers' sex affected the subsequent formation of donor relationships after 2008.

First, I tested whether gender inequality may have been caused by unseen changes in the population. I flagged educators who posted at least one project before September 2007 as having been pre-existing educators and everyone else was flagged as a new educator. I then split the sample into projects posted by pre-existing teachers and new teachers. I reran Models 1B-D on both samples to determine whether discrimination affected them differently.

Table S4 shows the results of the inequality model for new and old educators before and after sex is published. The results indicate that projects posted by educators who had posted a project before nationalization were not discriminated against except by their occupational score after 2007 (Models S1A and S2A). Projects posted by new teachers did experience the patterns of inequality found in the main study (Model S1B and S2B).

These results indicate that publishing teachers' identity did not affect teachers who were already on the website. The explanation I propose for this result is that these teachers had built relationships with donors that were independent of changes to the website. Pursing this hypothesis is difficult however as the lack of data on donors makes tracking them over time difficult. Instead, I derive two indicator measures for whether a teacher has a donor network.

The first indicator captured repeat donations: whether a project received a donation from donors who had given to the teacher before. For this measure, I counted any donation to a teacher from a donor account which had given a donation to that teacher. This included repeat donations to the same project. Most donors (71 percent) are recorded as donating only once. However, some of these are likely to be repeat donors who donated without logging into a donor account. Due to this missing data, I created a second indicator measure.

The second network indicator was whether a project received a donation from donors in the same zip code as the teacher. This is an indicator for whether teachers 
mobilized local, in-person networks to generate online donations. Donors are not required to provide personal information when they make donations. And, the information they do provide is relatively minimal and truncated for anonymization. I used zip code because it is commonly provided for donations: 48 percent of the 1.1 million donations have the donor's zip code. However, the zip code is truncated to the first three digits. This means I can only match teachers and donors who share the first three digits of their zip code. I also created a variable for whether educators received a donation from within their state. Donors provided their state in 71 percent of donations, thus the data coverage is better though the measure is much coarser. The same results held for both measures.

The proportion of donations that were repeat donations and from local donors ranged widely from between one third to two thirds of a project's total number of donations. Thus, teachers are not succeeding based solely on attracting new funders or mobilizing existing ones but a mix of the two. And, the two variables overlapped extensively. Teachers with more local donations also had more repeat donations (Pearson $\mathrm{r}=.40, \mathrm{p}<.001)$ and projects that received a donation from someone within the same zip code were twice as likely to receive a repeat donation $(t=208.8, p<.001)$. Among projects posted in 2008, educators who had been on the website before nationalization were almost twice as likely as new teachers to receive a repeat donation $(\mathrm{t}=-.11 .6, \mathrm{p}<$ .001). However, in 2008, educators who had been on DonorsChoose prior to nationalization were not more likely to receive donations from people in the same threedigit zip-code.

Table S5 shows models for the likelihood of successful funding when these two network measures are added as controls. The results show that gender discrimination reemerges for projects posted by teachers who were active prior to nationalization. Entering the variables one at a time (not shown) indicated that the suppression effect is due almost solely to repeat donations rather than local donors. This means that relationships with previous donors insulated educators from the effects of having their identity published.

If networks of repeat donors insulated educators from inequality, it stands to reason that, after educators' identity was published, new ties between teachers and donors may reflect the new discriminatory preferences. Specifically, to the extent that donors are influenced by gender, the subsequent tie formation process between teachers and repeat donors should also be affected by gender.

To test this, I estimated the likelihood that a project would receive a repeat donation in 2007, 2008, and 2009 conditional on the three dimensions of gender (see Table S6). The results show that there was very little gender inequality in which projects received repeat donations in 2007 and 2008 (Models S5 and S6). However, Model S7A shows that the same patterns of gender inequality emerge in 2009 for predicting repeat donations and all in the same direction as in the original models (Models 1A-D). This gendered shift in repeat donations was especially strong among projects posted by teachers who were joined the website after nationalization (Model S7B).

This emergence of gender inequality in tie formation follows the emergence of gender inequality in the system as whole. When DonorsChoose began publishing teachers' identities, donors began discriminating by gender and the new ties that formed in 2008 affected who would receive repeat donations in 2009. 

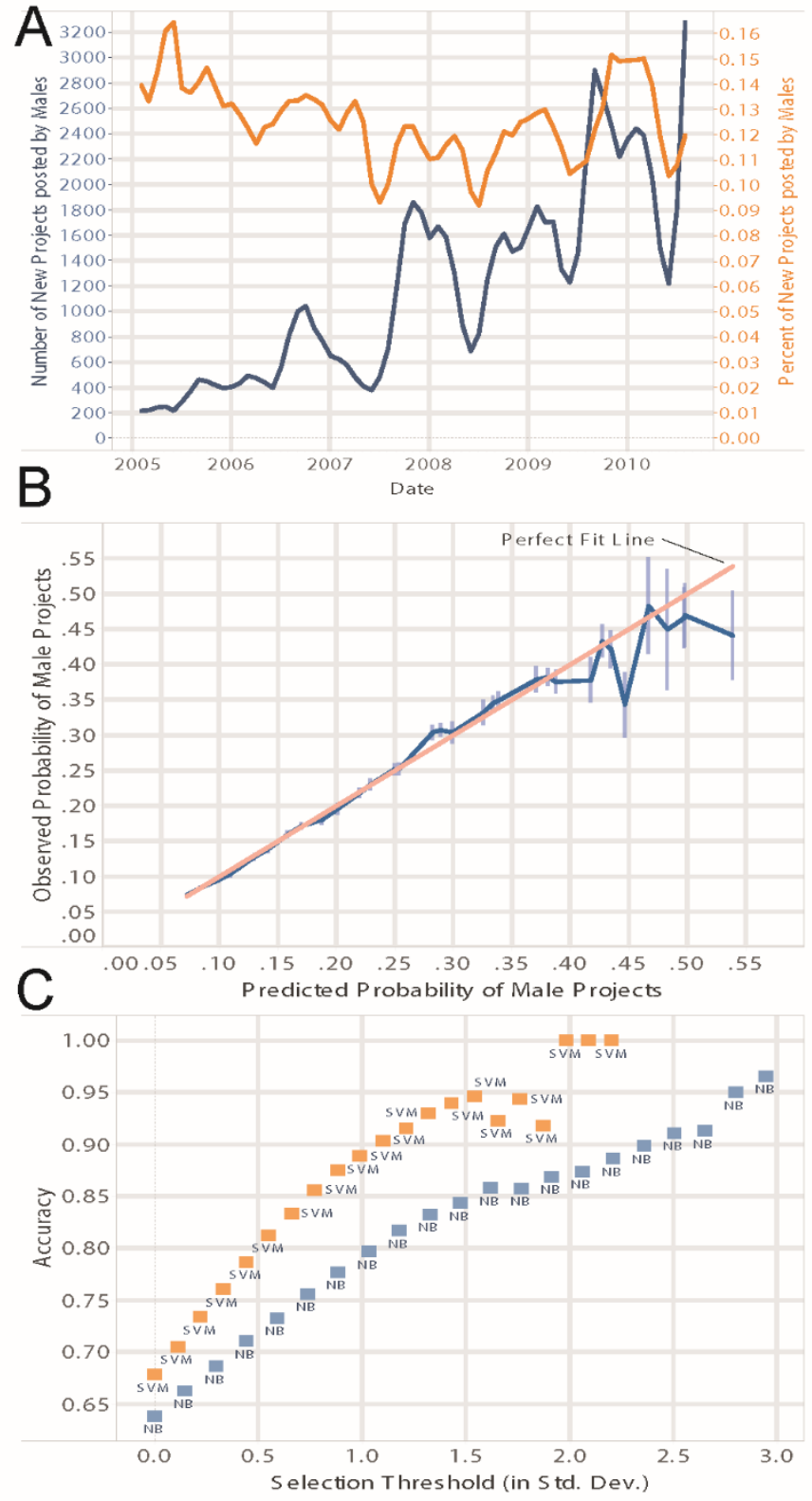

Fig. S1. Validation Graphs for Three Measures of Gender. (A) Male participation rates from 2005 -2010 binned every five months for smoothing. (B) Observed male concentration versus predicted probability a project is maleauthored with $95 \%$ confidence intervals. Prediction produced by model of occupational segregation in Table S1. (C) Model accuracy by classification threshold. Classification threshold corresponds to the point beyond which the classifier's estimate is included to calculate model accuracy. The higher the threshold, the higher the model's accuracy. 


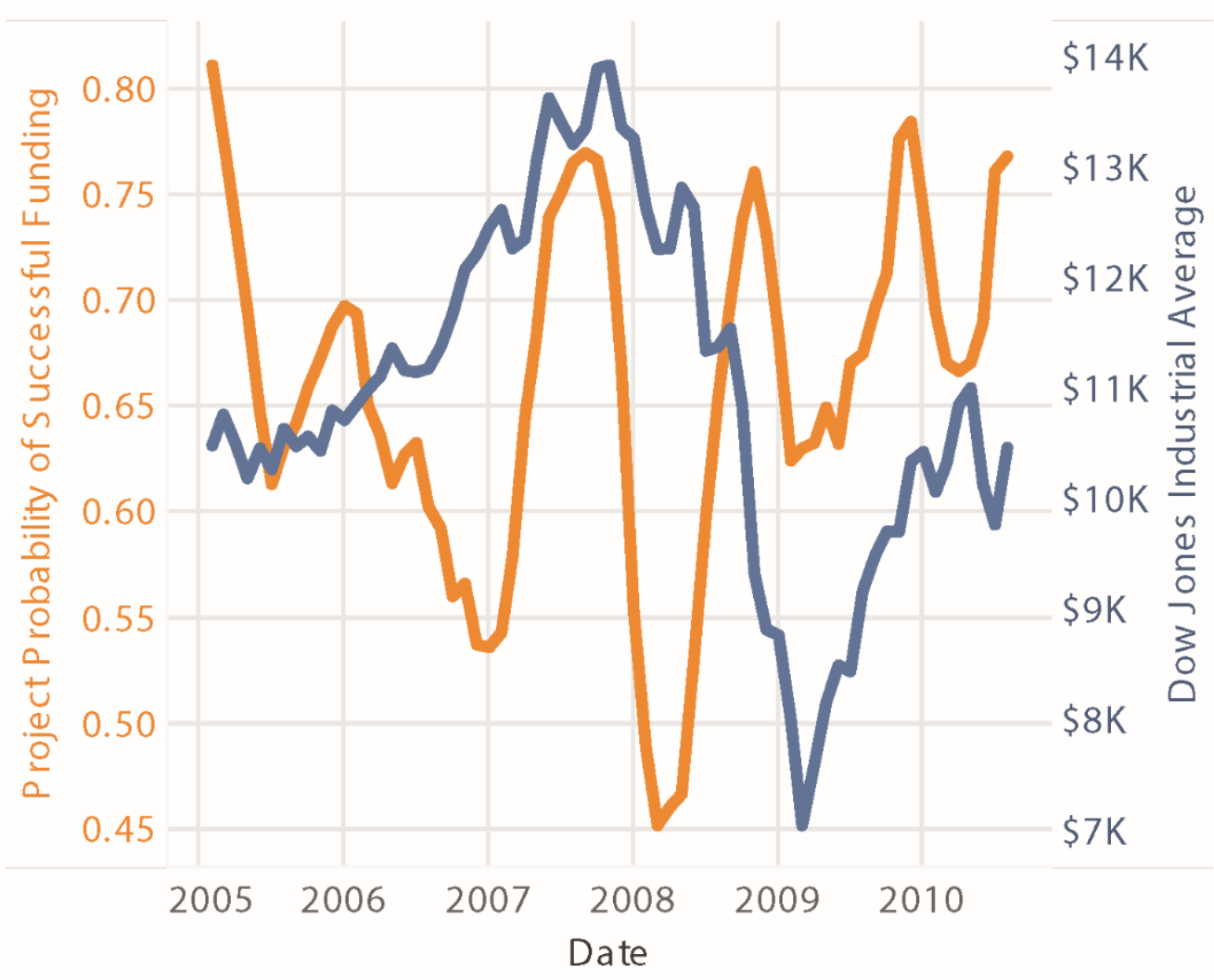

Fig. S2: The disjoint relationship between the monthly rate of success for projects on DonorsChoose and the Dow Jones Industrial Average from 2005 to 2010. 


\begin{tabular}{|c|c|}
\hline Variable & $\begin{array}{c}\text { Estimate } \\
\text { (Standard Error) }\end{array}$ \\
\hline Intercept & $-0.68^{* * *}$ \\
& $(0.02)$ \\
Grade PreK-2 & $-2.26^{* * *}$ \\
& $(0.02)$ \\
Grade 4-5 & $-1.21^{* * *}$ \\
& $(0.02)$ \\
Grade 6-8 & $-0.43^{* * *}$ \\
& $(0.02)$ \\
Special Ed & $-0.53^{* * *}$ \\
& $(0.03)$ \\
Arts & $0.20 * * *$ \\
& $(0.02)$ \\
Language & $-0.56^{* * *}$ \\
& $(0.01)$ \\
Social Science & $0.25^{* * *}$ \\
& $(0.02)$ \\
Sports & $0.67^{* * *}$ \\
& $(0.03)$ \\
Applied & $-0.17^{* * *}$ \\
& $(0.02)$ \\
Non-traditional & $0.16^{* * *}$ \\
& $(0.02)$ \\
Rural & $-0.46^{* * *}$ \\
& $(0.02)$ \\
Suburban & $-0.21^{* * *}$ \\
N & $(0.02)$ \\
228,655 \\
\hline
\end{tabular}

Table S1. Generalized linear model predicting the probability a project was written by a male teacher and defined as the measure of male concentration. Note: All categories are as defined by DonorsChoose.org. ${ }^{a}$ Null category is Grades 9$12,{ }^{b}$ Null category is STEM, and ${ }^{\mathrm{c}}$ Null category is urban. $* * * \mathrm{p}<.001$ (two-tailed z-tests) 


\begin{tabular}{|ll|ll|}
\hline \multicolumn{2}{|c|}{ Male-Typical Words } & \multicolumn{2}{c|}{ Female-Typical Words } \\
\hline kids & college & children & love \\
people & instruction & learners & want \\
student & course & readers & need \\
equipment & lack & supplies & feel \\
technology & quality & books & help \\
computers & funding & materials & fun \\
video & schools & read & families \\
instruments & based & skills & like \\
projector & american & learn & order \\
laptop & ability & paper & activities \\
physics & program & grade & able \\
music & material & make & possible \\
\hline
\end{tabular}

Table S2. Most informative $\mathbf{2 4}$ words for each sex from the Naïve Bayes classifier. Note, the words are based on extracting the top 200 most informative words per iteration of the NB classifier and using the Shannon Information score to measure how consistently the word indicates male or female authorship across all iterations. 


\begin{tabular}{|lccccc|}
\hline \multicolumn{1}{|c}{ Variable } & Mean & Std & Min & Max & N \\
\hline Funded & 0.70 & 0.46 & 0 & 1 & 56838 \\
Male & 0.50 & 0.50 & 0 & 1 & 56838 \\
Male Concentration & 0.21 & 0.12 & 0.01 & 0.60 & 56838 \\
Masculine Language & 0.00 & 0.78 & -2.95 & 3.42 & 56838 \\
Ask for Books & 0.20 & 0.40 & 0 & 1 & 56838 \\
Ask for Other & 0.07 & 0.25 & 0 & 1 & 56838 \\
Ask for Supplies & 0.35 & 0.48 & 0 & 1 & 56838 \\
Ask for Technology & 0.36 & 0.48 & 0 & 1 & 56838 \\
Ask for Trips & 0.02 & 0.13 & 0 & 1 & 56838 \\
Ask for Visitor & 0.00 & 0.05 & 0 & 1 & 56838 \\
Students Reached & 116 & 170 & 1 & 4000 & 56838 \\
Project Price & 718.26 & 1260.03 & 10.98 & 46323.17 & 56838 \\
School Poverty & 1.84 & 0.41 & 0 & 2 & 56838 \\
\hline
\end{tabular}

Table S3. Descriptive statistics of all variables used to estimate the probability of successful funding 


\begin{tabular}{|c|c|c|c|c|}
\hline \multirow{3}{*}{ Variables } & \multicolumn{2}{|c|}{2007} & \multicolumn{2}{|c|}{ 2008-2009 } \\
\hline & $\begin{array}{c}\text { Same } \\
\text { Teachers }\end{array}$ & $\begin{array}{c}\text { New } \\
\text { Teachers }\end{array}$ & $\begin{array}{c}\text { Same } \\
\text { Teachers }\end{array}$ & $\begin{array}{c}\text { New } \\
\text { Teachers }\end{array}$ \\
\hline & $\begin{array}{c}\text { Model } \\
\text { S1A } \\
\end{array}$ & $\begin{array}{c}\text { Model } \\
\text { S1B } \\
\end{array}$ & $\begin{array}{c}\text { Model } \\
\text { S2A } \\
\end{array}$ & \begin{tabular}{|c|} 
Model \\
S2B \\
\end{tabular} \\
\hline (Intercept) & $\begin{array}{l}8.095^{* * * *} \\
(0.587)\end{array}$ & $\begin{array}{l}9.009 * * * \\
(0.527)\end{array}$ & $\begin{array}{l}6.195 * * * \\
(0.516)\end{array}$ & $\begin{array}{l}6.466 * * * \\
(0.199)\end{array}$ \\
\hline $\mathrm{Male}^{\mathrm{S}}$ & $\begin{array}{l}0.024 \\
(0.050)\end{array}$ & $\begin{array}{l}0.062 \\
(0.039)\end{array}$ & $\begin{array}{l}0.038 \\
(0.043)\end{array}$ & $\begin{array}{l}0.077 * * * \\
(0.017)\end{array}$ \\
\hline Male Concentration ${ }^{\mathrm{S}, \mathrm{L}}$ & $\begin{array}{l}0.167 \\
(0.094)\end{array}$ & $\begin{array}{l}0.121 \\
(0.073)\end{array}$ & $\begin{array}{l}0.477 * * * \\
(0.085)\end{array}$ & $\begin{array}{l}0.565 * * * \\
(0.032)\end{array}$ \\
\hline Masculine Language $\mathrm{S}$ & $\begin{array}{l}0.259 * \\
(0.106)\end{array}$ & $\begin{array}{l}0.103 \\
(0.077)\end{array}$ & $\begin{array}{l}0.101 \\
(0.091)\end{array}$ & $\begin{array}{l}0.084 * * \\
(0.032)\end{array}$ \\
\hline Male $^{\mathrm{S}} \mathrm{x}$ Male Concentration $\mathrm{S}$ & $\begin{array}{l}0.016 \\
(0.042)\end{array}$ & $\begin{array}{l}-0.015 \\
(0.035)\end{array}$ & $\begin{array}{l}-0.006 \\
(0.038)\end{array}$ & $\begin{array}{l}-0.065^{* * *} \\
(0.015)\end{array}$ \\
\hline Male $^{\mathrm{S}}$ x Masc. Language ${ }^{\mathrm{S}}$ & $\begin{array}{l}-0.025 \\
(0.049)\end{array}$ & $\begin{array}{l}0.021 \\
(0.038)\end{array}$ & $\begin{array}{l}0.037 \\
(0.047)\end{array}$ & $\begin{array}{l}0.002 \\
(0.016)\end{array}$ \\
\hline Male Concentration ${ }^{\mathrm{S}, \mathrm{L}} \times$ Masc. Language $\mathrm{C}^{\mathrm{S}}$ & $\begin{array}{l}-0.008 \\
(0.082)\end{array}$ & $\begin{array}{l}-0.009 \\
(0.064)\end{array}$ & $\begin{array}{l}-0.024 \\
(0.076)\end{array}$ & $\begin{array}{l}0.164 * * * \\
(0.027)\end{array}$ \\
\hline $\begin{array}{l}\text { Male }^{\mathrm{S}} \text { x Male Concentration } \\
\text { Language }^{\mathrm{S}, \mathrm{L}} \text { x Masc. }\end{array}$ & $\begin{array}{l}0.011 \\
(0.039)\end{array}$ & $\begin{array}{l}0.018 \\
(0.033)\end{array}$ & $\begin{array}{l}0.047 \\
(0.036)\end{array}$ & $\begin{array}{l}-0.018 \\
(0.014)\end{array}$ \\
\hline Ask for Visitors & $\begin{array}{l}-0.031 \\
(0.732)\end{array}$ & $\begin{array}{l}-0.146 \\
(0.748)\end{array}$ & $\begin{array}{l}0.035 \\
(0.564)\end{array}$ & $\begin{array}{l}0.683 \\
(0.836)\end{array}$ \\
\hline Ask for Trips & $\begin{array}{l}0.177 \\
(0.283)\end{array}$ & $\begin{array}{l}-0.718 \\
(0.375)\end{array}$ & $\begin{array}{l}1.097 * * * \\
(0.302)\end{array}$ & $\begin{array}{l}1.812 * * * \\
(0.356)\end{array}$ \\
\hline Ask for Books & $\begin{array}{l}0.170 \\
(0.152)\end{array}$ & $\begin{array}{l}0.090 \\
(0.110)\end{array}$ & $\begin{array}{l}0.407 * * \\
(0.129)\end{array}$ & $\begin{array}{l}0.348 * * * \\
(0.046)\end{array}$ \\
\hline Ask for Technology & $\begin{array}{l}-0.596^{* * * *} \\
(0.138)\end{array}$ & $\begin{array}{l}-0.635^{* * * *} \\
(0.095)\end{array}$ & $\begin{array}{l}-0.536 * * * \\
(0.116)\end{array}$ & $\begin{array}{l}-0.382 * * * \\
(0.039)\end{array}$ \\
\hline Ask for Other & $\begin{array}{l}0.015 \\
(0.208)\end{array}$ & $\begin{array}{l}0.032 \\
(0.168)\end{array}$ & $\begin{array}{l}0.012 \\
(0.186)\end{array}$ & $\begin{array}{l}-0.303 * * * \\
(0.066)\end{array}$ \\
\hline \# of Students Reached ${ }^{\mathrm{L}}$ & $\begin{array}{l}-0.074 \\
(0.050)\end{array}$ & $\begin{array}{l}-0.109 * * \\
(0.036)\end{array}$ & $\begin{array}{l}-0.181 * * * \\
(0.044)\end{array}$ & $\begin{array}{l}-0.133 * * * \\
(0.015)\end{array}$ \\
\hline Price of Project ${ }^{\mathrm{L}}$ & $\begin{array}{l}-1.353^{* * *} \\
(0.079)\end{array}$ & $\begin{array}{l}-1.568 * * * \\
(0.074)\end{array}$ & $\begin{array}{l}-1.050 * * * \\
(0.069)\end{array}$ & $\begin{array}{l}-1.111^{* * * *} \\
(0.029)\end{array}$ \\
\hline School Poverty & $\begin{array}{l}0.485^{* * *} \\
(0.144) \\
\end{array}$ & $\begin{array}{l}0.690 * * * \\
(0.081) \\
\end{array}$ & $\begin{array}{l}0.540^{* * *} \\
(0.138) \\
\end{array}$ & $\begin{array}{l}0.735^{* * *} \\
(0.035) \\
\end{array}$ \\
\hline AIC & 2406 & 4712 & 3061 & 25479 \\
\hline $\mathrm{N}$ & 2449 & 4922 & 2851 & 24175 \\
\hline df & 27 & 27 & 27 & 27 \\
\hline
\end{tabular}

Table S4. Probability of successful funding before and after sex identification for new and pre-existing teachers on DonorsChoose. The years 2008 and 2009 are combined because there are too few teachers who persisted from 2007 to 2009. Monthly fixed effects were included but not reported for space. ${ }^{\mathrm{S}}$ Variable is z-score standardized; ${ }^{\mathrm{L}} \log$ of the variable is used; *** $\mathrm{p}<.001, * * \mathrm{p}<.01,{ }^{*} \mathrm{p}<.05$ (two-tailed $\mathrm{z}$-tests). 


\begin{tabular}{|c|c|c|c|c|}
\hline \multirow{3}{*}{ Variables } & \multicolumn{2}{|c|}{2007} & \multicolumn{2}{|c|}{ 2008-2009 } \\
\hline & $\begin{array}{c}\text { Same } \\
\text { Teachers }\end{array}$ & $\begin{array}{c}\text { New } \\
\text { Teachers }\end{array}$ & $\begin{array}{c}\text { Same } \\
\text { Teachers }\end{array}$ & $\begin{array}{c}\text { New } \\
\text { Teachers }\end{array}$ \\
\hline & $\begin{array}{c}\text { Model } \\
\text { S3A }\end{array}$ & $\begin{array}{c}\text { Model } \\
\text { S3B }\end{array}$ & $\begin{array}{c}\text { Model } \\
\text { S4A }\end{array}$ & $\begin{array}{c}\text { Model } \\
\text { S4B }\end{array}$ \\
\hline (Intercept) & $\begin{array}{l}8.766 * * * \\
(0.633)\end{array}$ & $\begin{array}{l}10.018 \text { *** } \\
(0.572)\end{array}$ & $\begin{array}{l}7.699 * * * \\
(0.65)\end{array}$ & $\begin{array}{l}7.839 * * * \\
(0.221)\end{array}$ \\
\hline Male $^{\mathrm{S}}$ & $\begin{array}{l}0.007 \\
(0.054)\end{array}$ & $\begin{array}{l}0.038 \\
(0.042)\end{array}$ & $\begin{array}{l}0.174 * * * \\
(0.052)\end{array}$ & $\begin{array}{l}0.062 * * * \\
(0.018)\end{array}$ \\
\hline Male Concentration ${ }^{\mathrm{S}, \mathrm{L}}$ & $\begin{array}{l}0.109 \\
(0.102)\end{array}$ & $\begin{array}{l}0.081 \\
(0.079)\end{array}$ & $\begin{array}{l}0.540 * * * \\
(0.105)\end{array}$ & $\begin{array}{l}0.531 * * * \\
(0.035)\end{array}$ \\
\hline Masculine Language $^{\mathrm{S}}$ & $\begin{array}{l}0.224 \\
(0.116)\end{array}$ & $\begin{array}{l}0.138 \\
(0.082)\end{array}$ & $\begin{array}{l}0.045 \\
(0.107)\end{array}$ & $\begin{array}{l}0.092 * * \\
(0.035)\end{array}$ \\
\hline Male $^{\mathrm{S}} \mathrm{x}$ Male Concentration $\mathrm{S}$ & $\begin{array}{l}0.017 \\
(0.046)\end{array}$ & $\begin{array}{l}-0.005 \\
(0.038)\end{array}$ & $\begin{array}{l}-0.136^{* *} \\
(0.046)\end{array}$ & $\begin{array}{l}-0.045 * * \\
(0.017)\end{array}$ \\
\hline Male $^{\mathrm{S}}$ x Masc. Language ${ }^{\mathrm{S}}$ & $\begin{array}{l}0.017 \\
(0.053)\end{array}$ & $\begin{array}{l}0.027 \\
(0.041)\end{array}$ & $\begin{array}{l}0.071 \\
(0.055)\end{array}$ & $\begin{array}{l}-0.007 \\
(0.017)\end{array}$ \\
\hline Male Concentration $^{\mathrm{S}, \mathrm{L}} \times$ Masc. Language ${ }^{\mathrm{S}}$ & $\begin{array}{l}0.012 \\
(0.088)\end{array}$ & $\begin{array}{l}-0.019 \\
(0.069)\end{array}$ & $\begin{array}{l}0.023 \\
(0.090)\end{array}$ & $\begin{array}{l}0.146 * * * \\
(0.030)\end{array}$ \\
\hline Male $^{\mathrm{S}} \times$ Male Concentration ${ }^{\mathrm{S}, \mathrm{L}} \times$ Masc. Language ${ }^{\mathrm{S}}$ & $\begin{array}{l}0.042 \\
(-0.120)\end{array}$ & $\begin{array}{l}0.011 \\
(0.035)\end{array}$ & $\begin{array}{l}-0.008 \\
(0.043)\end{array}$ & $\begin{array}{l}-0.012 \\
(0.015)\end{array}$ \\
\hline \# of Donations in Zip Code ${ }^{\mathrm{L}}$ & $\begin{array}{l}1.367 * * * \\
(0.166)\end{array}$ & $\begin{array}{l}1.973 * * * \\
(0.123)\end{array}$ & $\begin{array}{l}1.915^{* * *} \\
(0.180)\end{array}$ & $\begin{array}{l}1.711 * * * \\
(0.061)\end{array}$ \\
\hline \# of Repeat Donations ${ }^{\mathrm{L}}$ & $\begin{array}{l}2.576 * * * \\
(0.253)\end{array}$ & $\begin{array}{l}1.845 * * * \\
(0.217)\end{array}$ & $\begin{array}{l}3.627 * * * \\
(0.215)\end{array}$ & $\begin{array}{l}2.672 * * * \\
(0.074)\end{array}$ \\
\hline Ask for Visitors & $\begin{array}{l}-0.383 \\
(0.802)\end{array}$ & $\begin{array}{l}-0.357 \\
(0.858)\end{array}$ & $\begin{array}{l}0.345 \\
(0.698)\end{array}$ & $\begin{array}{l}-0.356 \\
(0.851)\end{array}$ \\
\hline Ask for Trips & $\begin{array}{l}0.18 \\
(0.297)\end{array}$ & $\begin{array}{l}-0.828^{*} \\
(0.386)\end{array}$ & $\begin{array}{l}1.298 * * * \\
(0.353)\end{array}$ & $\begin{array}{l}1.922 * * * \\
(0.425)\end{array}$ \\
\hline Ask for Books & $\begin{array}{l}0.157 \\
(0.161)\end{array}$ & $\begin{array}{l}0.106 \\
(0.116)\end{array}$ & $\begin{array}{l}0.397^{* *} \\
(0.148)\end{array}$ & $\begin{array}{l}0.311^{* * *} \\
(0.049)\end{array}$ \\
\hline Ask for Technology & $\begin{array}{l}-0.581 * * * \\
(0.149)\end{array}$ & $\begin{array}{l}-0.601 * * * \\
(0.101)\end{array}$ & $\begin{array}{l}-0.603 * * * \\
(0.140)\end{array}$ & $\begin{array}{l}-0.332 * * * \\
(0.043)\end{array}$ \\
\hline Ask for Other & $\begin{array}{l}0.108 \\
(0.217)\end{array}$ & $\begin{array}{l}0.009 \\
(0.178)\end{array}$ & $\begin{array}{l}0.060 \\
(0.221)\end{array}$ & $\begin{array}{l}-0.279 * * * \\
(0.071)\end{array}$ \\
\hline \# of Students Reached ${ }^{\mathrm{L}}$ & $\begin{array}{l}-0.060 \\
(0.052)\end{array}$ & $\begin{array}{l}-0.103 * * \\
(0.038)\end{array}$ & $\begin{array}{l}-0.115^{*} \\
(0.052)\end{array}$ & $\begin{array}{l}-0.119 * * * \\
(0.017)\end{array}$ \\
\hline Price of Project ${ }^{\mathrm{L}}$ & $\begin{array}{l}-1.551 * * * \\
(0.086)\end{array}$ & $\begin{array}{l}-1.803 * * * \\
(0.081)\end{array}$ & $\begin{array}{l}-1.580 * * * \\
(0.091)\end{array}$ & $\begin{array}{l}-1.421 * * * \\
(0.033)\end{array}$ \\
\hline School Poverty & $\begin{array}{l}0.533 * * * \\
(0.153)\end{array}$ & $\begin{array}{l}0.767 * * * \\
(0.088)\end{array}$ & $\begin{array}{l}0.782 * * * \\
(0.167)\end{array}$ & $\begin{array}{l}0.724 * * * \\
(0.038)\end{array}$ \\
\hline AIC & 2125 & 4193 & 2249 & 21793 \\
\hline $\mathrm{N}$ & 2449 & 4903 & 2851 & 24139 \\
\hline $\mathrm{df}$ & 29 & 29 & 29 & 29 \\
\hline
\end{tabular}

Table S5. Generalized linear model predicting the probability of success conditional on repeat donors and local donors for new and pre-existing teachers on

DonorsChoose. Monthly fixed effects were included but not reported for space. ${ }^{S}$

Variable is z-score standardized; ${ }^{\mathrm{L}}$ Log of the variable is used; $* * * \mathrm{p}<.001, * * \mathrm{p}<.01, *$ $\mathrm{p}<.05$ (two-tailed z-tests). 


\begin{tabular}{|c|c|c|c|c|}
\hline \multirow{3}{*}{ Variables } & 2007 & 2008 & \multicolumn{2}{|c|}{2009} \\
\hline & $\begin{array}{c}\text { All } \\
\text { Teachers }\end{array}$ & $\begin{array}{c}\text { All } \\
\text { Teachers }\end{array}$ & $\begin{array}{c}\text { All } \\
\text { Teachers }\end{array}$ & $\begin{array}{c}\text { New } \\
\text { Teachers }\end{array}$ \\
\hline & $\begin{array}{c}\text { Model } \\
\text { S5 }\end{array}$ & $\begin{array}{c}\text { Model } \\
\text { S6 }\end{array}$ & $\begin{array}{c}\text { Model } \\
\text { S7A }\end{array}$ & $\begin{array}{c}\text { Model } \\
\text { S7B }\end{array}$ \\
\hline (Intercept) & $\begin{array}{l}-2.181 * * * \\
(0.303)\end{array}$ & $\begin{array}{l}-3.42 * * * \\
(0.238)\end{array}$ & $\begin{array}{l}-3.343 * * * \\
(0.115)\end{array}$ & $\begin{array}{l}-3.215^{* * * *} \\
(0.127)\end{array}$ \\
\hline Male $^{\mathrm{s}}$ & $\begin{array}{l}0.038 \\
(0.028)\end{array}$ & $\begin{array}{l}-0.006 \\
(0.021)\end{array}$ & $\begin{array}{l}0.046 * * * \\
(0.013)\end{array}$ & $\begin{array}{l}0.059 * * * \\
(0.015)\end{array}$ \\
\hline Male Concentration ${ }^{\mathrm{S}, \mathrm{L}}$ & $\begin{array}{l}0.056 \\
(0.054)\end{array}$ & $\begin{array}{l}0.041 \\
(0.039)\end{array}$ & $\begin{array}{l}0.175 * * * \\
(0.025)\end{array}$ & $\begin{array}{l}0.207 * * * \\
(0.027)\end{array}$ \\
\hline Masculine Language ${ }^{\mathrm{s}}$ & $\begin{array}{l}0.011 \\
(0.059)\end{array}$ & $\begin{array}{l}0.028 \\
(0.043)\end{array}$ & $\begin{array}{l}0.032 \\
(0.026)\end{array}$ & $\begin{array}{l}0.001 \\
(0.028)\end{array}$ \\
\hline Male $^{\mathrm{s}}$ x Male Concentration ${ }^{\mathrm{s}}$ & $\begin{array}{l}-0.017 \\
(0.025)\end{array}$ & $\begin{array}{l}-0.024 \\
(0.018)\end{array}$ & $\begin{array}{l}-0.026^{*} \\
(0.012)\end{array}$ & $\begin{array}{l}-0.045^{* * *} \\
(0.013)\end{array}$ \\
\hline Male $^{\mathrm{S}} \mathrm{x}$ Masc. Language $\mathrm{S}$ & $\begin{array}{l}0.008 \\
(0.028)\end{array}$ & $\begin{array}{l}-0.018 \\
(0.021)\end{array}$ & $\begin{array}{l}0.089 * * * \\
(0.013)\end{array}$ & $\begin{array}{l}0.110 * * * \\
(0.014)\end{array}$ \\
\hline Male Concentration ${ }^{\mathrm{S}, \mathrm{L}} \mathrm{x}$ Masc. Language $\mathrm{S}^{\mathrm{S}}$ & $\begin{array}{l}-0.006 \\
(0.048)\end{array}$ & $\begin{array}{l}0.037 \\
(0.034)\end{array}$ & $\begin{array}{l}-0.035 \\
(0.022)\end{array}$ & $\begin{array}{l}-0.016 \\
(0.023)\end{array}$ \\
\hline Male $^{\mathrm{S}} \times$ Male Concentration ${ }^{\mathrm{S}, \mathrm{L}} \times$ Masc. Language $\mathrm{S}$ & $\begin{array}{l}0.013 \\
(0.022)\end{array}$ & $\begin{array}{l}0.004 \\
(0.016)\end{array}$ & $\begin{array}{l}-0.019 \\
(0.001)\end{array}$ & $\begin{array}{l}-0.038^{* * *} \\
(0.011)\end{array}$ \\
\hline Ask for Visitors & $\begin{array}{l}0.089 \\
(0.452)\end{array}$ & $\begin{array}{l}0.011 \\
(0.503)\end{array}$ & $\begin{array}{l}0.892 * * * \\
(0.133)\end{array}$ & $\begin{array}{l}0.035 \\
(0.449)\end{array}$ \\
\hline Ask for Trips & $\begin{array}{l}0.298 \\
(0.161)\end{array}$ & $\begin{array}{l}0.568 * * * \\
(0.169)\end{array}$ & $\begin{array}{l}0.316^{* * * *} \\
(0.086)\end{array}$ & $\begin{array}{l}0.349^{* *} \\
(0.114)\end{array}$ \\
\hline Ask for Books & $\begin{array}{l}0.098 \\
(0.069)\end{array}$ & $\begin{array}{l}0.045 \\
(0.055)\end{array}$ & $\begin{array}{l}-0.018 \\
(0.030)\end{array}$ & $\begin{array}{l}-0.002 \\
(0.032)\end{array}$ \\
\hline Ask for Technology & $\begin{array}{l}-0.285^{* * *} \\
(0.071)\end{array}$ & $\begin{array}{l}-0.125^{*} \\
(0.051)\end{array}$ & $\begin{array}{l}-0.126 * * * \\
(0.026)\end{array}$ & $\begin{array}{l}-0.095^{* * *} \\
(0.028)\end{array}$ \\
\hline Ask for Other & $\begin{array}{l}-0.207 \\
(0.116)\end{array}$ & $\begin{array}{l}-0.013 \\
(0.084)\end{array}$ & $\begin{array}{l}-0.225^{* * * *} \\
(0.050)\end{array}$ & $\begin{array}{l}-0.341 * * * \\
(0.058)\end{array}$ \\
\hline \# of Students Reached ${ }^{\mathrm{L}}$ & $\begin{array}{l}-0.046 \\
(0.025)\end{array}$ & $\begin{array}{l}-0.032 \\
(0.019)\end{array}$ & $\begin{array}{l}-0.033^{* * * *} \\
(0.010)\end{array}$ & $\begin{array}{l}-0.032 * * \\
(0.011)\end{array}$ \\
\hline Price of Project ${ }^{\mathrm{L}}$ & $\begin{array}{l}0.127 * * * \\
(0.037)\end{array}$ & $\begin{array}{l}0.259 * * * \\
(0.032)\end{array}$ & $\begin{array}{l}0.426 * * * \\
(0.015)\end{array}$ & $\begin{array}{l}0.390 * * * \\
(0.016)\end{array}$ \\
\hline School Poverty & $\begin{array}{l}-0.222 * * * \\
(0.060)\end{array}$ & $\begin{array}{l}0.042 \\
(0.049)\end{array}$ & $\begin{array}{l}-0.071 * * \\
(0.025)\end{array}$ & $\begin{array}{l}-0.087 * * \\
(0.026)\end{array}$ \\
\hline AIC & 8458 & 13904 & 39103 & 34579 \\
\hline $\mathrm{N}$ & 7352 & 10955 & 16035 & 14751 \\
\hline df & 27 & 27 & 27 & 27 \\
\hline
\end{tabular}

Table S6. Generalized linear model predicting the number of donations a project received from donors who donated to the teacher in prior projects before (Model S5), during (Model S6), and after sex identification (Models S7A and S7B). ${ }^{\mathrm{S}}$ Variable is $\mathrm{z}$-score standardized; ${ }^{\mathrm{L}} \log$ of the variable is used; *** $\mathrm{p}<.001, * * \mathrm{p}<.01, * \mathrm{p}<.05$ (two-tailed z-tests). 